Volume 6 Nomor 2, Agustus 2021, halaman 140 - 153.

\title{
The Euler, Heun, and Fourth Order Runge-Kutta Solutions to SEIR Model for the Spread of Meningitis Disease
}

\section{Penyelesaian Euler, Heun, dan Runge-Kutta Orde Empat atas Model SEIR pada Penyebaran Penyakit Meningitis}

\author{
Roberta Uron Hurit ${ }^{1, *}$, Sudi Mungkasi ${ }^{2}$ \\ ${ }^{1}$ Department of Mathematics Education, Faculty of Teacher Training and Education, \\ Institut Keguruan dan Teknologi Larantuka, Nusa Tenggara Timur, Indonesia, \\ uronhurit@gmail.com \\ ${ }^{2}$ Department of Mathematics, Faculty of Science and Technology, \\ Universitas Sanata Dharma, Yogyakarta, Indonesia, \\ sudi@usd.ac.id \\ *Corresponding Author
}

\begin{abstract}
ABSTRAK
Makalah ini menyelesaikan model SEIR (Susceptible-Exposed-Infected-Recovered) penyebaran penyakit meningitis secara numerik dengan tiga metode, yaitu metode Euler, metode Heun, dan metode Runge-Kutta orde empat (RK4). Metodologi penelitian ini meliputi lima langkah berturutturut, yaitu pemodelan matematika jenis SEIR, diskritisasi model, pemrograman komputer, simulasi numerik, dan pengamatan hasil simulasi. Dari simulasi, ketiga metode numerik tersebut memberikan penyelesaian dengan perilaku yang sama. Lebih lanjut, pola penyelesaian yang dihasilkan oleh ketiga metode tersebut juga sama dengan pola penyelesaian referensi yang dihasilkan oleh algoritma ode 45 dalam perangkat lunak MATLAB (sebagai catatan: penyelesaian referensi ode45 ini diambil, karena sampai saat ini penyelesaian eksak analitik model SEIR belum ditemukan). Hal ini memberikan kepercayaan pada kebenaran hasil simulasi dalam makalah ini. Secara teori, keakuratan metode RK4 lebih baik jika dibandingkan dengan keakuratan metode Euler dan metode Heun. Hasil numerik dalam makalah ini menunjukkan bahwa teori tersebut juga berlaku dalam simulasi penyebaran penyakit meningitis.
\end{abstract}

Kata Kunci: metode Euler, metode Heun, metode Runge-Kutta orde empat, model SEIR, penyebaran penyakit meningitis.

\section{ABSTRACT}

This paper solves the SEIR (Susceptible-Exposed-Infected-Recovered) model of meningitis disease spread numerically using three methods, namely, the Euler method, the Heun method, and the fourth order Runge-Kutta (RK4) method. Our research methodology consists of five steps consecutively, namely, mathematical modelling of the SEIR type, model discretisation, computer programming, numerical simulation, and observation of simulation results. Our simulations show that all the three numerical methods produce solutions with the same behaviour. Furthermore, the patterns of the solutions generated by the three methods are also the same as the pattern of the reference solution produced by the ode 45 algorithm in the MATLAB software (we note that: this ode 45 reference solution is taken, because until now the exact analytical solution of the SEIR model is not available). This gives confidence to the correctness of our simulation results in this paper. In theory, the accuracy of the RK4 method is better than those of the Euler and Heun methods. The numerical results in this paper show that the theory is also applicable in simulating the spread of meningitis disease.

Keywords: Euler method, Heun method, fourth order Runge-Kutta method, SEIR model, meningitis disease spread. 
How to Cite: Hurit, R. U., \& Mungkasi, S. (2021). The Euler, Heun, and Fourth Order Runge-Kutta Solutions to SEIR Model for the Spread of Meningitis Disease. Mathline: Jurnal Matematika dan Pendidikan Matematika, Vol. 6 No. 2, 140 - 153.

DOI: https://doi.org/10.31943/mathline.v6i2.176

\section{PRELIMINARY}

One of infectious diseases is meningitis. This disease infects many people with a fairly high mortality rate in the world. The largest patient population comes from countries in Africa and Asia, including Indonesia. The causes of meningitis are the bacteria Neisseria meningitidis, Haemophilus influenzae, Streptococcus pneumoniae, and Listeria monocytogenes (Asamoah, et al., 2018). One technique that can be used to analyze the dynamics of disease spread is by using mathematical models (Allmandan \& Rhodes, 2004; Ozalp \& Demirci, 2011; Hurint, et al., 2017; Hurit, 2020). Mathematical models are formulated based on the characteristics of the disease. In this paper, the mathematical model that will be used is the SEIR epidemic model, in which the population is divided into four groups, namely: susceptible (S) individuals who are susceptible to meningitis, exposed (E) individuals who have actually been infected with the disease but have not been able to transmit it, infected (I) individuals who have infected and can transmit the disease, and recovered $(\mathrm{R})$ individuals who have recovered from the disease.

This paper aims to solve the SEIR model of the spread of meningitis using the Euler method, Heun method, and the fourth order Runge-Kutta method (RK4). The Euler method is a numerical method with the first order of accuracy. The Heun method is a method with the second order of accuracy known as an improvement of the Euler method. The RK4 method is a method with the fourth order of accuracy. The simulation results of the three methods will be seen whether they have similarities in the behavior of the solution. The same behavior will convince the authors and readers about the correctness of the simulation results in this paper. Furthermore, the numerical results in this paper verify that in simulating the spread of meningitis, it is also true that the RK4 method is more accurate than the Heun method and the Euler method, and the Heun method is more accurate than the Euler method.

The rest of this paper describes the methods, results and discussion, as well as conclusion. The methods section provides the SEIR model and numerical schemes for solving the model; the numerical schemes include the scheme of the Euler method, the scheme of the Heun method, and the scheme of the RK4 method. The results and discussion section contains graphs of numerical simulations and their discussion as well as a 
comparison of absolute errors of the solutions obtained from the three applied methods. At the end, the paper will close with some concluding remarks.

\section{METHODS}

Our research method lies on programming and simulation, that is, (a) computer programming of the Euler method, Heun method, and the RK4 method; and (b) simulations to solve the SEIR model of the spread of meningitis. The flow of research on the spread of meningitis (as our methodology) sequentially consists of five stages, namely:

1. development of SEIR model for the spread of meningitis;

2. numerical discretizations of SEIR model based on Euler, Heun, and RK4 methods;

3. computer programming of the discretizations of SEIR model into the MATLAB software;

4. numerical simulations of the spread of meningitis using the MATLAB computer programs; and

5. observation of the solution graphs generated by the MATLAB computer programs.

In more detail, the following describes the form of the SEIR model, the Euler method, the Heun method, and the RK4 method.

\section{SEIR Model}

In the SEIR model, the population is divided into four subpopulations, namely, susceptible $S(t)$ which is a subpopulation susceptible to disease, exposed $E(t)$ which is a subpopulation infected but not yet been able to transmit the disease, infected $I(t)$ which is a subpopulation that has been infected and is actively transmitting the disease, and recovered $R(t)$ which is a subpopulation recovered from the disease (Allmandan \& Rhodes, 2004). Here $t$ is time variable. A transfer diagram of the spread of disease in a population can be presented in Figure 1, which includes the vaccination factor.

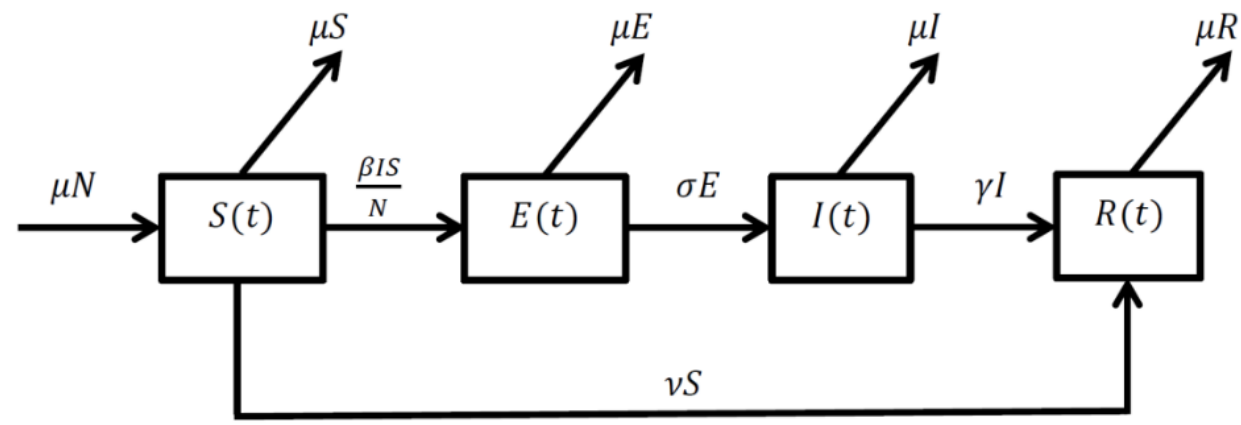

Figure 1. Transfer Diagram of the Spread of Meningitis Involving Vaccination 
The transfer diagram of the SEIR model in Figure 1 shows the transition of each state as a dynamic within the population. In the initial state, the individual can be said to be susceptible which can transfer to an exposed individual, but this individual has not been fully infected with the disease. If the exposed individual becomes fully infected, then over time the exposed population enters the infected population. Thus, the exposed population is reduced and it can be said that the individual becomes infected. This results in an increase in the infected population. Furthermore, after the individual is infected and then recovers, this individual is included in the recovered category. Individuals who have received the vaccine are assumed to be immune to meningitis, so they are immediately included in the recovered group. Each population in this SEIR model has natural death in each subpopulation, either caused by the disease itself or other factors. This means that the natural death factor also causes a decrease (subtraction) in the susceptible, exposed, infected, and recovered subpopulations (Allmandan \& Rhodes, 2004; Hurit, 2020). As additional assumptions, the total population in the system is constant, and there is no migration.

Based on the diagram in Figure 1 and the explanation above, the formulation of the SEIR model for the spread of meningitis is as follows:

$$
\begin{aligned}
& \frac{d S}{d t}=\mu(N-S)-\beta \frac{S I}{N}-v S, \\
& \frac{d E}{d t}=\beta \frac{S I}{N}-(\mu+\sigma) E, \\
& \frac{d I}{d t}=\sigma E-(\mu+\gamma) I, \\
& \frac{d R}{d t}=\gamma I-\mu R+v S,
\end{aligned}
$$

with variable and parameter descriptions are given in Table 1 . Here, the unit for the time variable $t$ is day.

Table 1. Parameters Involved in the SEIR Model

\begin{tabular}{llc}
\hline Parameter & Description & Unit \\
\hline$\beta$ & transmission rate from susceptible to infected individual & day $^{-1}$ \\
$\gamma$ & recovery rate of each infected individual & day $^{-1}$ \\
$\sigma$ & movement rate from exposed to infected individual & day $^{-1}$ \\
$\mu$ & individual birth and death rates in each group & day $^{-1}$ \\
$\nu$ & vaccination rate for susceptible individual & day $^{-1}$ \\
\hline
\end{tabular}


As written in Table 1, parameter $\beta$ is a parameter that functions to control how quickly an individual moves from susceptible to exposed individuals. Parameter $\sigma$ describes the rate for the movement of the exposed population to the infected population; parameter $\gamma$ describes the infected population becoming resistant (recovered). There are two additional parameters to see the transition system for the spread of meningitis, namely: parameter $\mu$ which is a parameter of natural birth and death rates that is not affected by disease, and parameter $v$ which describes the rate of vaccination applied to the susceptible individuals. This vaccination is given to susceptible populations with the aim of making susceptible individuals recovered directly without becoming exposed or infected (Allmandan \& Rhodes, 2004).

\section{Euler Method}

An initial value problem for differential equations can be expressed as follows (Butcher, 2003; Agrawal, 2016):

$$
\frac{d y}{d t}=f(t, y), \quad a \leq t \leq b, \quad y(a)=\alpha .
$$

Here, $t$ is the time variable, which is free; $y$ is the dependent variable with respect to $t$; $f$ is a function dependent on $t$ and $y ; a, b$, and $\alpha$ are known constants.

The Euler method for problem (5) is expressed as:

$$
y_{i+1}=y_{i}+h f\left(t_{i}, y_{i}\right)
$$

where $i=0,1,2, \ldots, N-1$ and $h=t_{i+1}-t_{i}$ and $y_{0}=y(a)=\alpha$ for a chosen positive integer $N$.

\section{Heun Method}

The Heun method is commonly known as the improvement of the Euler method and its order of accuracy is higher than Euler's. This method is the result of a generalization of the Euler method by Heun (Chandio \& Memon, 2010; Ningsi, 2019). The Heun method consists of predictor and corrector steps, in which the predictor is calculated using the Euler method. The Heun iteration formula for problem (5) can be written as follows:

$$
\begin{aligned}
& \text { Predictor: } \\
& \bar{y}_{i+1}=y_{i}+h f\left(t_{i}, y_{i}\right),
\end{aligned}
$$

Corrector:

$$
y_{i+1}=y_{i}+\frac{h}{2}\left[f\left(t_{i}, y_{i}\right)+f\left(t_{i+1}, \bar{y}_{i+1}\right)\right],
$$


where $i=0,1,2, \ldots, N-1$ and $h=t_{i+1}-t_{i}$ and $y_{0}=y(a)=\alpha$ for a chosen positive integer $N$.

\section{RK4 Method}

The RK4 method has been widely used, because it has a high order of accuracy and is more accurate than the two previous mentioned methods. The RK4 method for problem (5) has the following form (Fredilina \& Werthi, 2018; Huzaimah, 2016):

$$
y_{i+1}=y_{i}+\frac{1}{6}\left(k_{1}+2 k_{2}+2 k_{3}+k_{4}\right)
$$

in which:

$$
\begin{aligned}
& k_{1}=h f\left(t_{i}, y_{i}\right), \\
& k_{2}=h f\left(t_{i}+\frac{1}{2} h, y_{i}+\frac{1}{2} k_{1}\right), \\
& k_{3}=h f\left(t_{i}+\frac{1}{2} h, y_{i}+\frac{1}{2} k_{2}\right), \\
& k_{4}=h f\left(t_{i}+h, y_{i}+k_{3}\right),
\end{aligned}
$$

where $i=0,1,2, \ldots, N-1$ and $h=t_{i+1}-t_{i}$ and $y_{0}=y(a)=\alpha$ for a chosen positive integer $N$.

\section{RESULTS AND DISCUSSION}

This section reports our simulation results and provides discussion about them. Numerical programming and simulation are done using the MATLAB software. For all simulations, initial values and parameter values are presented in Table 2. It should be noted that all parameter values and initial values in Table 2 are assumptions. The value of $h$ in Table 2 is chosen specifically with the consideration that the simulation results will be quite accurate and the simulation process is relatively short (only a few seconds of simulation on a laptop computer).

This section contains four subsections. The first subsection contains the solution to the SEIR model using the Euler method. The second subsection reports the solution to the SEIR model using the Heun method. The third subsection contains the solution to the SEIR model using the RK4 method. The fourth subsection contains a comparison of the errors of the Euler method, the Heun method, and the RK4 method. 
Table 2. Descriptions and Values of Parameters and Initial Values of Variables in Simulations of the Spread of Meningitis (Hurit, 2020)

\section{Description}

\section{Variable and}

Parameter

Value

\begin{tabular}{lcc}
\hline Transmission rate from susceptible to infected individual & $\beta$ & 0.90 \\
Recovery rate of each infected individual & $\gamma$ & 0.20 \\
Movement rate from exposed to infected individual & $\sigma$ & 0.50 \\
Individual birth and death rates in each group & $\mu$ & 0.12 \\
Vaccination rate for susceptible individual & $v$ & 0.50 \\
Time variable & $t$ & {$[0,30]$} \\
Initial value of variable $S$ & $S(0)$ & 10 \\
Initial value of variable $E$ & $E(0)$ & 5 \\
Initial value of variable $I$ & $I(0)$ & 0 \\
Initial value of variable $R$ & $R(0)$ & 0 \\
Time step for the discretized SEIR model & $h$ & 0.1 \\
\hline
\end{tabular}

\section{Solving SEIR Model using Euler Method}

The formulation of the Euler method to solve the SEIR model of the spread of meningitis can be written as follows:

$$
\begin{aligned}
& S_{n+1}=S_{n}+h\left(\mu\left(N-S_{n}\right)-\beta \frac{S_{n} I_{n}}{N}-v S_{n}\right), \\
& E_{n+1}=E_{n}+h\left(\beta \frac{S_{n} I_{n}}{N}-(\mu+\sigma) E_{n}\right), \\
& I_{n+1}=I_{n}+h\left(\sigma E_{n}-(\mu+\gamma) I_{n}\right), \\
& R_{n+1}=R_{n}+h\left(\gamma I_{n}-\mu R_{n}+v S_{n}\right),
\end{aligned}
$$

where $n=0,1,2, \ldots, N-1$ for an integer $N ; h=t_{n+1}-t_{n}$, and $t_{n}$ is discrete time value. Using the initial values and parameter values from Table 2, simulation results are obtained as shown in Figure 2. It should be noted that the exact analytical solution of the SEIR model has not yet been found (not available until this paper is written). 


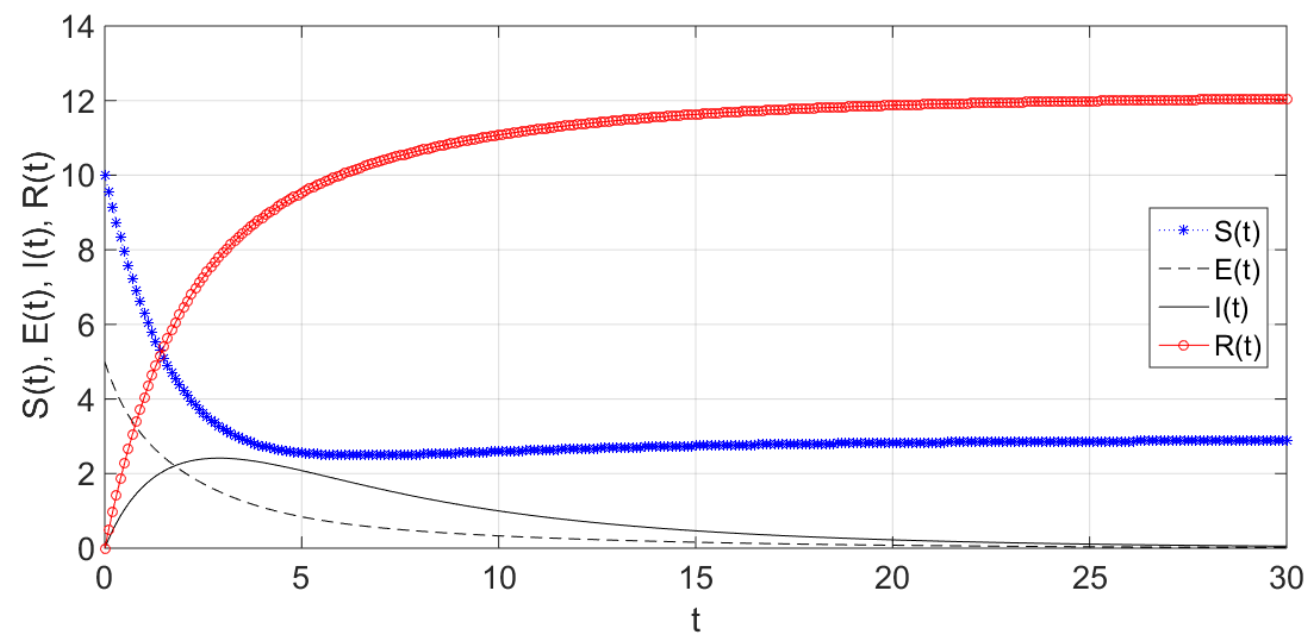

Figure 2. Solution to the SEIR Model of Meningitis Spread Using the Euler Method

Figure 2 shows the solution to the SEIR epidemic model of meningitis spread using the Euler method. Over time, the exposed and the infected subpopulations approach asymptotically to zero. At the same time, the susceptible and the recovered subpopulations moves towards their equilibrium values.

\section{Solving SEIR Model using Heun Method}

The Heun method for solving the SEIR model which is considered to have a predictor-corrector numerical scheme is as follows:

Predictor:

$$
\begin{aligned}
& \bar{S}_{n+1}=S_{n}+h\left(\mu\left(N-S_{n}\right)-\beta \frac{S_{n} I_{n}}{N}-v S_{n}\right), \\
& \bar{E}_{n+1}=E_{n}+h\left(\beta \frac{S_{n} I_{n}}{N}-(\mu+\sigma) E_{n}\right), \\
& \bar{I}_{n+1}=I_{n}+h\left(\sigma E_{n}-(\mu+\gamma) I_{n}\right), \\
& \bar{R}_{n+1}=R_{n}+h\left(\gamma I_{n}-\mu R_{n}+v S_{n}\right),
\end{aligned}
$$

Corrector:

$$
\begin{aligned}
& S_{n+1}=S_{n}+\frac{h}{2} {\left[\left(\mu\left(N-S_{n}\right)-\beta \frac{S_{n} I_{n}}{N}-v S_{n}\right)\right.} \\
&\left.+\left(\mu\left(N-\bar{S}_{n+1}\right)-\beta \frac{\bar{S}_{n+1} \bar{I}_{n+1}}{N}-v \bar{S}_{n+1}\right)\right], \\
& E_{n+1}=E_{n}+\frac{h}{2}\left[\left(\beta \frac{S_{n} I_{n}}{N}-(\mu+\sigma) E_{n}\right)+\left(\beta \frac{\bar{S}_{n+1} \bar{I}_{n+1}}{N}-(\mu+\sigma) \bar{E}_{n+1}\right)\right],
\end{aligned}
$$


148 The Euler, Heun, and Fourth Order Runge-Kutta Solutions to SEIR Model for the Spread of Meningitis Disease

$$
\begin{aligned}
& I_{n+1}=I_{n}+\frac{h}{2}\left[\left(\sigma E_{n}-(\mu+\gamma) I_{n}\right)+\left(\sigma \bar{E}_{n+1}-(\mu+\gamma) \bar{I}_{n+1}\right)\right], \\
& R_{n+1}=R_{n}+\frac{h}{2}\left[\left(\gamma I_{n}-\mu R_{n}+v S_{n}\right)+\left(\gamma \bar{I}_{n+1}-\mu \bar{R}_{n+1}+v \bar{S}_{n+1}\right)\right],
\end{aligned}
$$

where $n=0,1,2, \ldots, N-1$ for an integer $N ; h=t_{n+1}-t_{n}$, and $t_{n}$ is discrete time value.

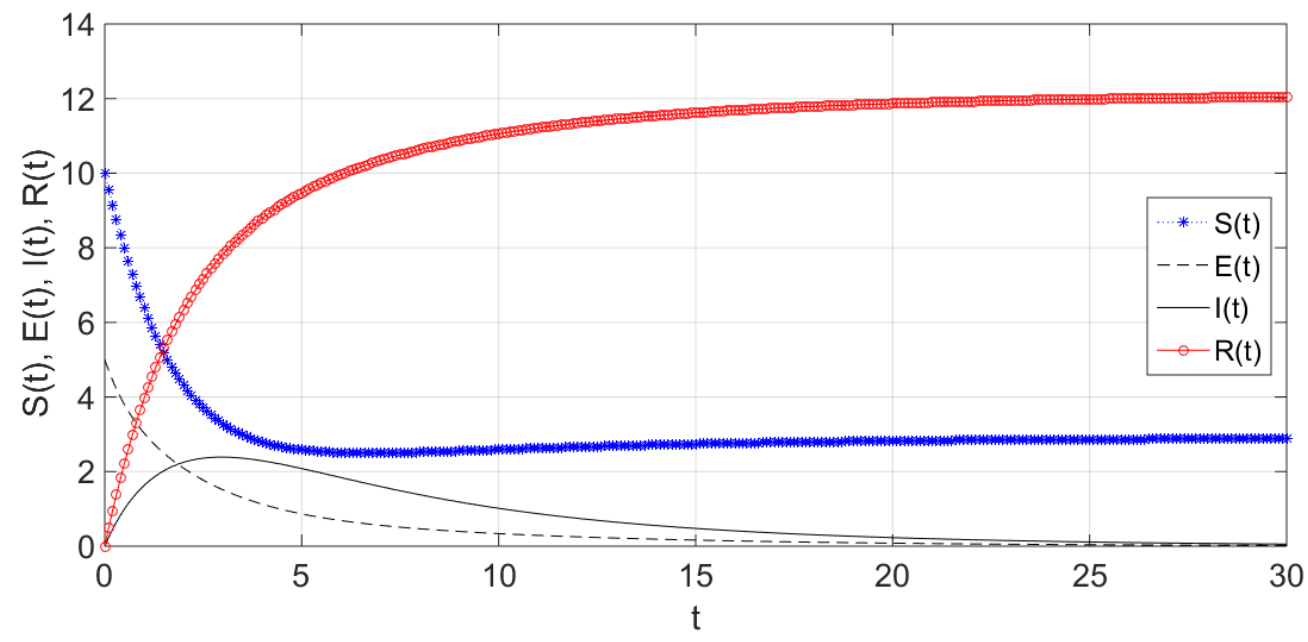

\section{Figure 3. Solution to the SEIR Model of Meningitis Spread Using the Heun Method}

Figure 3 shows the simulation results of the solution to the SEIR epidemic model using the Heun method. This graph is similar to the simulation results using the Euler method. Over time, the majority of individuals in the system fall into the recovered group and a small proportion are in the susceptible group. Over a long period of time, the numbers of individuals in the exposed and infected groups are almost zero.

\section{Solving SEIR Model using RK4 Method}

The application of the RK4 method to the SEIR model of the spread of meningitis provides the following auxiliary variables:

$$
\begin{aligned}
& k_{1 S}=h\left(\mu\left(N-S_{n}\right)-\beta \frac{S_{n} I_{n}}{N}-v S_{n}\right), \\
& k_{1 E}=h\left(\beta \frac{S_{n} I_{n}}{N}-(\mu+\sigma) E_{n}\right), \\
& k_{1 I}=h\left(\sigma E_{n}-(\mu+\gamma) I_{n}\right), \\
& k_{1 R}=h\left(\gamma I_{n}-\mu R_{n}+v S_{n}\right), \\
& k_{2 S}=h\left(\mu\left(N-\left(S_{n}+\frac{1}{2} k_{1 S}\right)\right)-\frac{\beta}{N}\left(S_{n}+\frac{1}{2} k_{1 S}\right)\left(I_{n}+\frac{1}{2} k_{1 I}\right)-v\left(S_{n}+\frac{1}{2} k_{1 S}\right)\right), \\
& k_{2 E}=h\left(\frac{\beta}{N}\left(S_{n}+\frac{1}{2} k_{1 S}\right)\left(I_{n}+\frac{1}{2} k_{1 I}\right)-(\mu+\sigma)\left(E_{n}+\frac{1}{2} k_{1 E}\right)\right),
\end{aligned}
$$




$$
\begin{aligned}
& k_{2 I}=h\left(\sigma\left(E_{n}+\frac{1}{2} k_{1 E}\right)-(\mu+\gamma)\left(I_{n}+\frac{1}{2} k_{1 I}\right)\right), \\
& k_{2 R}=h\left(\gamma\left(I_{n}+\frac{1}{2} k_{1 I}\right)-\mu\left(R_{n}+\frac{1}{2} k_{1 R}\right)+v\left(S_{n}+\frac{1}{2} k_{1 S}\right)\right), \\
& k_{3 S}=h\left(\mu\left(N-\left(S_{n}+\frac{1}{2} k_{2 S}\right)\right)-\frac{\beta}{N}\left(S_{n}+\frac{1}{2} k_{2 S}\right)\left(I_{n}+\frac{1}{2} k_{2 I}\right)-v\left(S_{n}+\frac{1}{2} k_{2 S}\right)\right), \\
& k_{3 E}=h\left(\frac{\beta}{N}\left(S_{n}+\frac{1}{2} k_{2 S}\right)\left(I_{n}+\frac{1}{2} k_{2 I}\right)-(\mu+\sigma)\left(E_{n}+\frac{1}{2} k_{2 E}\right),\right. \\
& k_{3 I}=h\left(\sigma\left(E_{n}+\frac{1}{2} k_{2 E}\right)-(\mu+\gamma)\left(I_{n}+\frac{1}{2} k_{2 I}\right)\right), \\
& k_{3 R}=h\left(\gamma\left(I_{n}+\frac{1}{2} k_{2 I}\right)-\mu\left(R_{n}+\frac{1}{2} k_{2 R}\right)+v\left(S_{n}+\frac{1}{2} k_{2 S}\right)\right), \\
& k_{4 S}=h\left(\mu\left(N-\left(S_{n}+k_{3 S}\right)\right)-\frac{\beta}{N}\left(S_{n}+k_{3 S}\right)\left(I_{n}+k_{3 I}\right)-v\left(S_{n}+k_{3 S}\right)\right), \\
& k_{4 E}=h\left(\frac{\beta}{N}\left(S_{n}+k_{3 S}\right)\left(I_{n}+k_{3 I}\right)-(\mu+\sigma)\left(E_{n}+k_{3 E}\right)\right), \\
& k_{4 I}=h\left(\sigma\left(E_{n}+k_{3 E}\right)-(\mu+\gamma)\left(I_{n}+k_{3 I}\right)\right), \\
& k_{4 R}=h\left(\gamma\left(I_{n}+k_{3 I}\right)-\mu\left(R_{n}+k_{3 R}\right)+v\left(S_{n}+k_{3 S}\right)\right),
\end{aligned}
$$

so the numerical scheme of the RK4 method for the SEIR model is as follows:

$$
\begin{aligned}
& S_{n+1}=S_{n}+\frac{1}{6}\left(k_{1 S}+2 k_{2 S}+2 k_{3 S}+k_{4 S}\right), \\
& E_{n+1}=E_{n}+\frac{1}{6}\left(k_{1 E}+2 k_{2 E}+2 k_{3 E}+k_{4 E}\right), \\
& I_{n+1}=I_{n}+\frac{1}{6}\left(k_{1 I}+2 k_{2 I}+2 k_{3 I}+k_{4 I}\right), \\
& R_{n+1}=R_{n}+\frac{1}{6}\left(k_{1 R}+2 k_{2 R}+2 k_{3 R}+k_{4 R}\right) .
\end{aligned}
$$

Here, $n=0,1,2, \ldots, N-1$ for an integer $N ; h=t_{n+1}-t_{n}$, and $t_{n}$ is discrete time value.

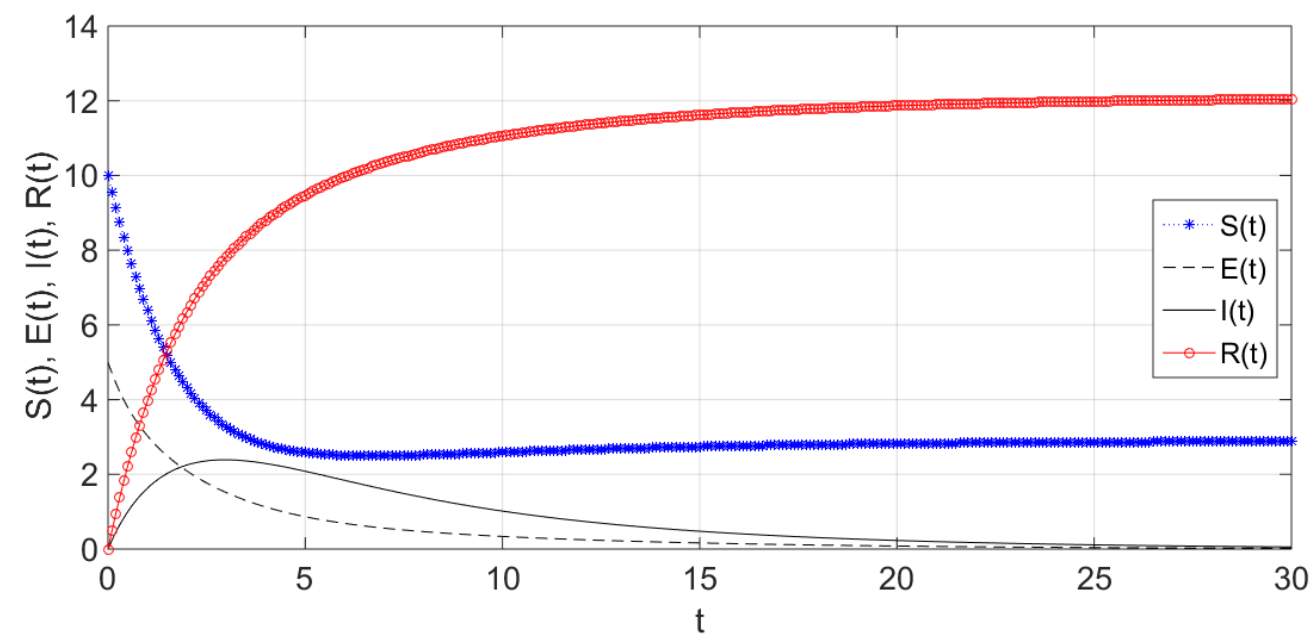

Figure 4. Solution to the SEIR Model of Meningitis Spread Using the RK4 Method 
Figure 4 shows the simulation results of the solution to the SEIR epidemic model using the RK4 method. In theory, this graph is more accurate than the graph in Figure 2 of the Euler method and the graph in Figure 3 of the Heun method. This is because the Euler method has the first order of accuracy, the Heun method has the second order of accuracy, while the RK4 method has the fourth order of accuracy (Butcher, 2003). These orders of accuracy are influenced by the accuracy of the numerical integration process of the derivative of the function involved in the differential equations (Butcher, 2003). The graphs in Figure 2, Figure 3, and Figure 4 show the same behavior and similar results for the susceptible group $S(t)$, the exposed group $E(t)$, the infected group $I(t)$, and the recovered group $R(t)$. It appears that as time goes on, the recovered group gets larger approaching its equilibrium, while the exposed group and infected group get smaller towards zero, and the susceptible group goes to its constant equilibrium. This shows that the vaccination applied in this population system has been successfully applied to eradicate the spread of meningitis.

\section{Error Comparison between Euler, Heun, and RK4 Solutions}

This subsection is devoted to a comparison of the absolute errors between the solutions produced by the Euler method (Figure 2), the Heun method (Figure 3), the RK4 method (Figure 4) and the reference solution shown in Figure 5. We observe that Figures 25 depict the same behavior of the solutions to the SEIR model. To confirm which method is the most accurate among the Euler method, Heun method, and RK4 method in simulating the spread of meningitis, the errors of these three methods need to be quantified. It should be noted that the exact analytical solution of the SEIR model expressed by equations (1)-(4) has not been found so far. Therefore, the reference solution is taken from the ode 45 algorithm in the MATLAB software. The relative tolerance and absolute tolerance that we specified in ode45 are $2.3 \times 10^{-14}$, so that this reference solution is believed to be accurate. The tolerance value of $2.3 \times 10^{-14}$ is chosen, because this value is easy to remember and close enough to the default tolerance $2.22045 \times 10^{-14}$ of the ode 45 algorithm of the MATLAB software.

From Table 3, we observe that the errors from the largest to the smallest are the errors of Euler method, Heun method, and RK4 method, respectively. This means that the accuracy of the Heun method is between the accuracy of Euler method and that of the RK4 method. Furthermore, the Euler method produces solution which is least accurate, and the RK4 method produces the most accurate solution among the three applied methods. 


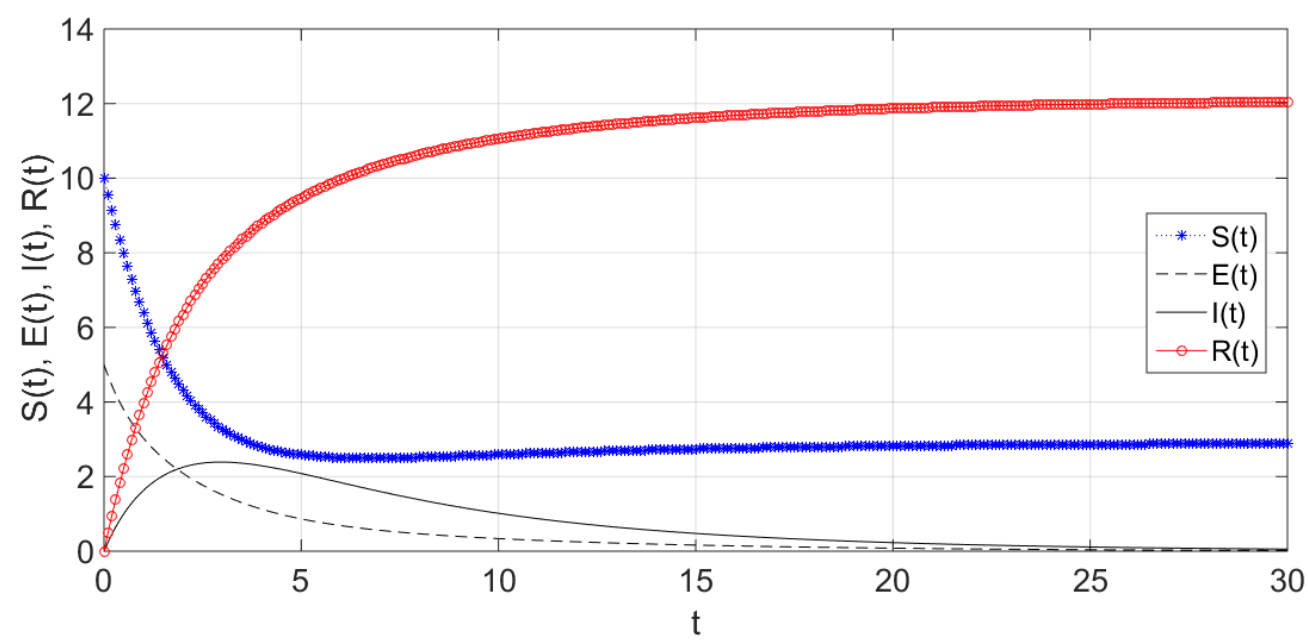

Figure 5. Solution to the SEIR Model of Meningitis Spread Using MATLAB's ode45

Table 3. Comparison of Absolute Errors of Solutions

by Euler Method, Heun Method, and RK4 Method

\begin{tabular}{lcccc}
\hline $\begin{array}{l}\text { Solving } \\
\text { Method }\end{array}$ & $\begin{array}{c}\text { Absolute Error } \\
\text { of Variable } \boldsymbol{S}\end{array}$ & $\begin{array}{c}\text { Absolute Error } \\
\text { of Variable } \boldsymbol{E}\end{array}$ & $\begin{array}{c}\text { Absolute Error } \\
\text { of Variable } \boldsymbol{I}\end{array}$ & $\begin{array}{c}\text { Absolute Error } \\
\text { of Variable } \boldsymbol{R}\end{array}$ \\
\hline Euler & $1.28 \times 10^{-2}$ & $1.03 \times 10^{-2}$ & $1.13 \times 10^{-2}$ & $2.30 \times 10^{-2}$ \\
Heun & $2.74 \times 10^{-4}$ & $1.69 \times 10^{-4}$ & $2.15 \times 10^{-4}$ & $2.65 \times 10^{-4}$ \\
RK4 & $6.64 \times 10^{-8}$ & $4.13 \times 10^{-8}$ & $1.22 \times 10^{-7}$ & $3.79 \times 10^{-8}$ \\
\hline
\end{tabular}

From the results of the comparison of errors between the Euler method, Heun method, and the RK4 method, it is suggested that in solving the mathematical model of the spread of meningitis, the RK4 method should be used. This RK4 method can be applied to solve other models of disease spread, for example in problems discussed by Mungkasi (2021, 2020a, 2020b) and Mungkasi et al. (Pratiwi \& Mungkasi, 2021; Simangunsong \& Mungkasi, 2021; Lede \& Mungkasi, 2019). This research can be developed and expanded for problems in other topics (Kovalnogov, et al., 2021; Yang, et al., 2019; Guan \& Shen, 2018; Karasözen, 1998).

\section{CONCLUSION}

Solutions to the SEIR model in this paper are shown as graphs generated numerically using MATLAB programs based on the Euler method, Heun method, and RK4 method. Each accuracy of the numerical solutions of the three methods is measured by absolute error which is based on the reference solution of the ode45 algorithm in the MATLAB software. The 
reference solution of the ode 45 algorithm is taken, because the exact analytical solution for the SEIR model has not yet been found. The graphs of the solutions to the SEIR model show that the numerical solutions produced using the three methods have the same behavior as the reference solution. Theoretically, the accuracy of the RK4 method is higher than that of the Euler method and that of the Heun method. This theory has been confirmed in this paper numerically. From the simulation results, it is concluded that the three methods can be applied to solve the SEIR model of meningitis spread, and that vaccination can be applied to eradicate the spread of meningitis in the human population.

\section{THANK-YOU NOTE}

This paper was developed based on the unpublished master's thesis of the first author (Roberta Uron Hurit) under the supervision of the second author (Sudi Mungkasi) at Universitas Sanata Dharma, Yogyakarta in year 2020. The SEIR model, numerical schemes, and parameter values as well as the initial values of the variables are taken from the thesis, whereas other parts of this paper are new development made by the two authors. Both authors thank Institut Keguruan dan Teknologi Larantuka as well as Universitas Sanata Dharma for all the support provided in this research.

\section{REFERENCES}

Agrawal, N. (2016). Application of Modified Euler's Method in Obtaining Numerical Solution of Swing Equation. International Journal of Scientific Research Engineering \& Technology, 5 (11), 561-567.

Allmandan, E. S., \& Rhodes, J. A. (2004). Mathematical Models in Biology: An Introduction. Cambridge: Cambridge University Press.

Asamoah, J. K. K., Nyabadza, F., Seidu, B., Chand, M., \& Dutta, H. (2018). Mathematical Modelling of Bacterial Meningitis Transmission Dynamics with Control Measures. Computational and Mathematical Methods in Medicine, 3 (1), 2657461.

Butcher, J. C. (2003). Numerical Methods for Ordinary Differential Equation. Chichester: John Wiley \& Sons.

Chandio, M. S., \& Memon, A. G. (2010). Improving the Efficiency of Heun's Method. Sindh University Research Journal (Science Series), 42 (2), 85-88.

Fredilina, K. Q., \& Werthi, K. T. (2018). Pemodelan Matematika dengan Metode Runge Kutta untuk Penyakit Campak Menggunakan MATLAB R2010a. Jurnal Teknologi Informasi dan Komputer, 4 (2), 150-155.

Guan, L., \& Shen, J. (2018). Bifurcation Analysis about a Mathematical Model of Somitogenesis Based on the Runge-Kutta Method. Wireless Personal Communications, 103, 221-230.

Hurint, R. U., Ndii, M., \& Lobo, M. (2017). Analisis Sensitivitas Model Epidemi SEIR. Online Journal of Natural Science, 6 (1), 22-28.

Hurit, R. U. (2020). Penyelesaian Model SEIR untuk Penyebaran Penyakit Meningitis Menggunakan Metode Euler, Metode Heun dan Metode Runge-Kutta Orde Empat. 
Master's Thesis, Department of Mathematics Education, Faculty of Teacher Training and Education, Universitas Sanata Dharma, Yogyakarta.

Huzaimah, H. (2016). Metode Analitik dan Metode Runge-Kutta Orde 4 dalam Penyelesaian Persamaan Getaran Pegas Teredam. Bachelor's Thesis, Department of Mathematics, Faculty of Science and Technology, Universitas Islam Negeri Maulana Malik Ibrahim, Malang.

Karasözen, B. (1998). Runge-Kutta Methods for Hamiltonian Systems in Non-Standard Symplectic Two-Form. International Journal of Computer Mathematics, 66 (1-2), 113-122.

Kovalnogov, V. N., Simos, T. E., \& Tsitouras, C. (2021). Runge-Kutta Pairs Suited for SIRType Epidemic Models. Mathematical Methods in the Applied Sciences, 44 (6), 52105216.

Lede, Y. K., \& Mungkasi, S. (2019). Performance of the Runge-Kutta Methods in Solving a Mathematical Model for the Spread of Dengue Fever Disease. AIP Conference Proceedings, 2202, 020044.

Mungkasi, S. (2021). Variational Iteration and Successive Approximation Methods for a SIR Epidemic Model with Constant Vaccination Strategy. Applied Mathematical Modelling, 90, 1-10.

Mungkasi, S. (2020a). Improved Variational Iteration Solutions to the SIR Model of Dengue Fever Disease for the Case of South Sulawesi. Journal of Mathematical and Fundamental Sciences, 52 (3), 297-311.

Mungkasi, S. (2020b). Successive Approximation, Variational Iteration, and MultistageAnalytical Methods for a SEIR Model of Infectious Disease Involving Vaccination Strategy. Communication in Biomathematical Sciences, 3 (2), 114-126.

Ningsi, G. P. (2019). Penerapan Metode Euler, Metode Heun, dan Metode Iterasi Variasional dalam Menyelesaikan Sistem Transmisi Tuberkulosis. Tesis. Universitas Sanata Dharma, Yogyakarta.

Ozalp, N., \& Demirci, E. (2011). A Fractional Order SEIR Model with Vertical Transmission. Mathematical and Computer Modeling, 54 (1-2), 1-6.

Pratiwi, C. D., \& Mungkasi, S. (2021). Euler's and Heun's Numerical Solutions to a Mathematical Model of the Spread of COVID-19. AIP Conference Proceedings, 2353, 030110.

Simangunsong, L., \& Mungkasi, S. (2021). Fourth Order Runge-Kutta Method for Solving a Mathematical Model of the Spread of HIV-AIDS. AIP Conference Proceedings, 2353, 030092.

Yang, M., Fang, H., Wang, F., Jia, H., Lei, J., \& Zhang, D. (2019). The Three Dimension First-Order Symplectic Partitioned Runge-Kutta Scheme Simulation for GPR Wave Propagation in Pavement Structure. IEEE Access, 7, 151705-151712. 